\title{
DOES ECO-EFFICENCY REDUCE THE COST OF EQUITY CAPITAL? EMPIRICAL EVIDENCE FROM INDONESIA
}

\author{
Lisa Alviani \\ Directorate of Taxation \\ Ministry of Finance, Republic of Indonesia \\ (alvianilisa@gmail.com) \\ Mahfud Sholihin \\ Faculty of Economics and Business \\ Universitas Gadjah Mada \\ (mahfud@ugm.ac.id)
}

\begin{abstract}
The objective of this study is to examine the effect of eco-efficiency on the cost of equity capital. The study hypothesizes that the implementation of eco-efficiency reduces the cost of equity capital. Using manufacturing companies listed on the Indonesian Stock Exchange for the period 2010-2012 as data, and controlling for beta, company size, Book to Market ratio, and leverage; the study finds that the implementation of eco-efficiency may reduce the cost of equity capital. The findings suggest that companies should implement ecoefficency.
\end{abstract}

Keywords: cost of equity capital; eco-efficiency; ISO 14001; environmental accounting

\section{INTRODUCTION}

The World Business Council for Sustainable Development (WBCSD) defines eco-efficiency as the provision of goods and services at competitive prices that satisfy the needs and improve the quality of human life, as well as progressively reduce the impact on the environment and reduce the intensity of resource usage to a minimum (WBCSD, 2000). Bran et al. (2011) suggested that reducing water consumption, energy consumption, and the amount of waste generated would reduce the costs incurred by a company. Reduction in water consumption and waste that are accompanied by stability or improvements in production will increase efficiency and improve the environmental performance of a company.

Several studies have investigated the ecoefficiency concept and its influence on companies that implement it. Guenster et al. (2006) found that eco-efficiency had a positive effect on the economic performance and value of companies in the United States. Likewise, research conducted by Sinkin et al. (2008) revealed that increasing the effectiveness of business processes and simultaneously reducing the environmental impact increased the value of US companies. Al-Najjar and Anfimiadou (2012) conducted a study in the UK and found that companies with eco-efficiency benefited from it over their competitors who did not employ it, and also enjoyed better access to capital, which therefore increased their value.

Previous research examining eco-efficiency had been more oriented towards investigating the benefits of eco-efficiency that increased the value of the firm. Hansen and Mowen (2007) argued that one of the advantages of implementing eco-efficiency was that the company which implement it would have a lower cost of capital. However, this proposition, to the best of our knowledge, has never been tested empirically, particularly in developing countries. Therefore, the objective of this study is to examine the effect of eco-efficiency on the cost of equity capital for companies listed on the Indonesian Stock Exchange.

This study differs from previous research related to ecoefficency because this study was 
conducted in a developing country, namely Indonesia. Indonesia was chosen because it is a country with a relatively poor environmental performance, ranked 112th out of 178 in the World, and whose environmental performance index was 44.36 on a scale of 100 in 2013 (Yale University, 2014). In addition, Indonesia's capital market is one that is still developing and investors have not been fully able to respond to disclosures made by companies in their annual reports (Utami, 2005).

We selected manufacturing companies as our samples because data from Greenpeace Indonesia indicated that waste from the manufacturing sector was now out of control, causing long-term damage to human health and the environment (Greenpeace Indonesia, 2012). Another reason why we selected manufacturing companies was because the sector accounts for the largest contribution to Indonesia's Gross Domestic Product (GDP). Manufacturing accounts for $23.94 \%$ of the total GDP in Indonesia (BPS, 2013).

Using a sample of manufacturing companies listed on the Indonesian Stock Exchange from 2010 to 2012, this study provides evidence that eco-efficiency is able to lower the cost of equity capital. That is, companies that implement ecoefficiency have a lower cost of equity capital than companies that do not implement it.

The next part of this study will be the literature review and the development of the hypothesis. After that, the method will be presented, followed by the results of the research. This article closes with conclusions, limitations, and suggestions for future research.

\section{LITERATURE REVIEW AND HYPOTHESIS DEVELOPMENT}

\section{The Concept of Eco-efficiency}

WBCSD (2000) explains that eco-efficiency is a business concept because eco-efficiency talks about the language of business, i.e. ecoefficiency will generate good business by increasing production efficiency. The aims of eco-efficiency are: (1) To reduce the consumption of natural resources, including minimizing the use of energy, raw materials, water, and soil; (2) to reduce the negative impacts of business on the environment, including minimizing pollution of the air and water, reducing waste, and reduce the spread of toxic substances; (3) to increase the value of products or services by providing more benefits to consumers related to the functionality, flexibility, and shape of the products, and to provide goods or services desired by the consumers. This means consumers will have the same benefits but with fewer raw materials and resources.

The concept of eco-efficiency has also been highlighted by Bran et al. (2011) who suggested that it was the improved efficiency and environmental performance of the company. This efficiency resulted from increased production stability and was accompanied by cost reduction results from reduced water consumption, energy consumption, and a reduction in the amount of waste generated by companies.

According to Hansen and Mowen (2007), eco-efficiency meant that organizations could produce more profitable goods and services while at the same time reducing their negative environmental impact, resource consumption, and costs. Further they added that eco-efficiency had implications for the increase in efficiency which came from improved environmental performance. According to them, there were several causes and incentives for the efficient use of natural resources, including : (1) Customers want products that are cleaner, that is products that are produced without harming the environment; (2) employees prefer to work in a company that is environmentally responsible so this will result in greater productivity; (3) a company acting responsibly towards the environment tends to obtain external benefits, such as lower costs of capital and insurance; (4) good environmental performance can generate significant social benefits; (5) focusing on improving the environmental performance creates a desire in managers to innovate and explore new opportunities; (6) a reduction in environmental costs can create a competitive advantage.

Eco-efficiency can be measured in several ways. The WBCSD (2000) measures eco- 
efficiency by dividing the value of the product or service by the environmental impacts. The value of the product is the quantity of products or services produced and the environmental impact is the consumption of energy, raw materials and water, as well as greenhouse gas emissions produced by the company.

Sarkis and Talluri (2004) introduced a model for eco-efficiency measurement that compared energy usage with energy inputs (raw materials), labor inputs, sulfur emissions, nitrogen emissions, and carbon dioxide emissions, with the following formula:

$$
E_{k}=\frac{U E_{k}}{E N_{k}+L_{k}+S O_{k}+N O_{k}+C O_{k}}
$$

$E_{k}$ is the value of efficiency, $U E_{k}$ is usable energy, $E N_{k}$ is energy inputs (raw materials), $L_{k}$ is labor inputs, $S O_{k}$ is sulfur emissions, $N O_{k}$ is nitrogen emissions, and $\mathrm{CO}_{k}$ is carbon dioxide emissions.

In addition to measures used by the WBCSD (2000) and Sarkis and Talluri (2004), Sinkin et al. (2008) provided an alternative eco-efficiency assessment that was straight forward. They used the acquisition of ISO 14001 certification for assessing whether eco-efficiency was carried out by the company. Sinkin et al. (2008) used this valuation because the objectives of ecoefficiency corresponded to the objectives of ISO 14001. This measurement was the same as the one used by Marshall and Brown (2003) and AlNajjar and Anfimiadou (2012).

\section{Eco-efficiency and Legitimacy Theory}

The legitimacy theory states that an organization or company must ensure that their operations are carried out in accordance with the norms upheld by society. In addition, the organization must determine whether their activities will be accepted by society or other external parties (Deegan and Rankin, 1996). Dowling and Pfeffer (1975) in Ghozali and Chariri (2007) suggested that the legitimacy theory was very useful to an organization because it could be used to analyze organizational behavior. The legitimacy theory states that a company will not have legitimacy if the activities that it carries out are not appropriate or they differ from the prevailing values in the community. This difference is called the legitimacy gap.

A legitimacy gap can affect the performance of a company. Therefore, the gap must be reduced by identifying and reducing the activities that differ from the community's values . Based on the legitimacy theory, it can be argued there is a likely relationship between eco-efficiency and the cost of equity capital. That is, companies with better eco-efficiency face less legal risks because the legitimacy gap between the company and the community's values is small (Waddock and Graves, 1997 in El-Ghoul et al., 2011), hence, reducing the cost of equity capital. This is consistent with Feldman et al. (1997) who argued that a company having good environmental performance will also experience a small legitimacy gap, thus reducing the risk that must be accepted by the investor (Feldman et al., 1997 in El-Ghoul et al., 2011). Meanwhile, companies that have a poor environmental performance will make investors want high returns to compensate for the risk that they take. This causes the company's cost of equity capital to increase (Heinkel et al, 2001).

\section{Previous relevant studies and hypothesis}

Much research on eco-efficiency and its effects has been carried out. In their research, Guenster et al. (2006) found that eco-efficiency had a positive effect on the economic performance of companies in the United States. In their study, eco-efficiency was measured using the values developed by Innovest Strategic Value Advisors. Data from Innovest Strategic Value Advisors used more than 60 quantitative and qualitative criteria to measure ecoefficiency. The results of the study by Guenster et al. (2006) stated that companies with ecoefficiency had a higher Return on Assets (RoA) and market value.

Sinkin et al. (2008) showed that increasing the effectiveness of business processes and simultaneously reducing the environmental impact would increase the value of the US companies. They used ISO 14001 as a proxy to 
measure the eco-efficiency of the company. Companies that acquired the ISO 14001 certification were given the value of 1 , while companies that did not receive the ISO 14001 certification were those companies without ecoefficiency and they were given the value of 0 . The results showed that companies with ecoefficiency had a higher value compared to companies without eco-efficiency.

Al-Najjar and Anfimiadou (2012) obtained similar results to those obtained by Sinkin et al. (2008). The difference between the research by Al-Najjar and Anfimiadou (2012) and the research conducted by Sinkin et al. (2008) was the samples. Al-Najjar and Anfimiadou (2012) conducted their study in the UK. Measurements of eco-efficiency in their research used only the ISO 14001 requirements. Companies that obtained ISO 14001 were those with ecoefficiency. The results of these studies showed that eco-efficiency increased the value of the firms.

In addition to research on eco-efficiency and its effect on company value, previous research related to this study is research into the cost of equity capital. For example, Botosan (1997) investigated the effect of disclosure on the cost of equity capital. The results showed that the more voluntary disclosure there was, the lower the cost of equity capital. This was due to voluntary disclosure reducing information asymmetry. Subsequent research was conducted by El-Ghoul et al. (2011). They argued that a company with a higher value in terms of Corporate Social Responsibility (CSR) had a lower cost of equity capital. That is, investments made to improve employee relations, environmental policies, and better product strategies, would reduce the cost of equity capital. Their research took its sample from companies in the United States. The cost of equity capital was measured using a version of the Ohlson Model (1995) which had been modified by Botosan (1997).

Mangena et al. (2012) found that the disclosure of intellectual capital negatively affected the cost of equity capital. A company with a higher level of disclosure of intellectual capital had a lower cost of equity capital than a company with a low level of disclosure of intellectual capital. Disclosure of intellectual capital would reduce information asymmetry and thus lower the company's cost of equity capital. Mangena et al. (2012) used a Price-earnings Growth Model to measure the cost of equity capital. This study used a sample of companies in the UK.

There has been research on the cost of equity capital in Indonesia, such as that carried out by Utami (2005). This study found that earnings management had a positive effect on the cost of equity capital. Utami (2005) used the Ohlson Model (1995) which had been adapted to the data available in Indonesia for measuring the cost of equity capital of the country's manufacturing companies.

Research on investor attitudes towards environmental disclosure had been conducted by Jacobs et al. (2008). They suggested that investors responded differently to the disclosure of environmental information. Investors tended to respond to the company's announcement of environmental awards and third party certification rather than to the company's own disclosures regarding the environment.

Given those studies, we hypothesize:

Ha1: The implementation of eco-efficiency has a negative effect on the company's cost of equity capital.

\section{RESEARCH METHOD}

\section{Variables and their Measurements}

In this study, the independent variable was eco-efficiency and the dependent variable was the cost of equity capital. Based on research by Botosan (1997) and Mangena et al. (2010), this study incorporates: The risk sensitivity of the stock (BETA) which was measured using weekly stock returns data; company size (SIZE) which was measured using market capitalization; Book to Market ratio (BtM) which was calculated by dividing the book value by the market value; and the level of corporate debt (LEV) which was calculated using the total debt divided by the total assets as control variables. 
Consistent with the research conducted by Marshall and Brown (2003), Sinkin et al., (2008), and Al-Najjar and Anfimiadou (2012), eco-efficiency in this study was measured using ISO14001 which is a standard that is used to recognize a company's environmental management system. A company that was ISO 14001 certified was deemed to be a company with ecoefficiency and coded 1, while companies that were not ISO 14001 certified were ones without eco-efficiency and coded 0.

The dependent variable in this study was the cost of equity capital. Cost of equity capital is the portion needed to satisfy the investors or the minimum rate of return on capital, which must be produced by the company in excess of the funds that have been invested. Following previous studies in Indonesia (Utami, 2005), we used the Ohlson model (1995) which had been modified using the Formula :

$$
r=\left(B_{t}+X_{t+1}-P_{t}\right) / P_{t}
$$

$r$ is the cost of equity capital, $B_{t}$ is the book value per share period $t, X_{t+1}$ is the earnings per share in period $t+1$, and $P_{t}$ is the stock price at period $t$.

The Ohlson Model (1995) used forecast earnings per share which are calculated by analyzing the assessed earnings per share in period $t$ +1 . In Indonesia, such data were not available, so Utami (2005) used a random walk model for estimating earnings per share in period $t+1$. The basis for using the random walk model was the study conducted by Rini (2002) and Qizam (2001). Those studies concluded that the behavior of profits in Indonesia followed the random walk model.

\section{Sample}

The sample of this study was manufacturing companies listed on the Indonesian Stock Exchange during the period from 2010 to 2012. Samples were taken from all the companies listed on the Indonesian Stock Exchange using the purposive sampling method. Selected samples had the following criteria: a. It was a manufacturing company whose shares were listed on the Indonesian Stock Exchange in 2012.

b. It published an Annual Report during the study period (2010 to 2012) which included financial statements.

c. It had a fiscal year that ended on the $31^{\text {st }}$ of December.

d. It had not been delisted from the Stock Exchange during the period of the study (2010 to 2012).

e. It had a positive equity value during the study period (2010 to 2012).

The data were taken from the companies' financial reports published by the Indonesian Capital Market Directory. Market capitalization value, the book value per share, and the stock price were obtained from the IDX Fact Book.

To test the hypothesis we used the following model;

$$
\begin{aligned}
\operatorname{CoE}_{i t}= & \alpha+\beta_{1} E C O_{i t}+\beta_{2} B_{E T A_{i t}}+ \\
& \beta_{3} \operatorname{SIZE}_{i t}+\beta_{4} \text { BTM }_{i t}+\beta_{5} L E V_{i t}+e_{i t}
\end{aligned}
$$

where :

$\mathrm{CoE}_{i t}$ : Cost of equity of company in period $t$, measured by book value per share period $t$ plus earnings per share in period $t+1$ minus stock price at period $t$ and then divided by stock price at period $t$,

$E C O_{i t}$ : Eco-efficiency of company i in period $\mathrm{t}$, measured by a dummy variable set to 1if a company had ISO 14001 and 0 without it,

$B E T A_{i t}$ : Sensitivity to the market share of company $\mathrm{i}$ in period $\mathrm{t}$, measured using weekly stock return data,

$S I Z E_{i t}$ : Size of company i in period t, measured using natural log of assets,

$B M T_{i t}$ : Book to Market ratio of company i in period $\mathrm{t}$,

$L E V_{i t}$ : Leverage of company $\mathrm{i}$ in period $\mathrm{t}$, measured as the ratio of total debt to total assets), and

$e_{i t} \quad$ : Error estimate 


\section{Results and Discussions}

Using predefined criteria, this study yielded data from 64 companies (see table 1). Hence we had a pool of 192 firms-year data.

Table 1. Number of Sample

\begin{tabular}{clc}
\hline No. & \multicolumn{1}{c}{ Criteria } & Amount \\
\hline 1 & $\begin{array}{l}\text { Manufacturing companies whose } \\
\text { shares are listed on the Stock }\end{array}$ & 118 \\
& $\begin{array}{l}\text { Exchange in 2012. } \\
2\end{array}$ & $\begin{array}{l}\text { Manufacturing companies that } \\
\text { published Annual Reports during the } \\
\text { study period (2010-2012) and include } \\
\text { financial statements. }\end{array}$ \\
3 & $\begin{array}{l}\text { Companies with a financial year } \\
\text { ending 31 }\end{array}$ & 77 \\
4 & $\begin{array}{l}\text { Companies that were not delisted } \\
\text { from the Stock Exchange during the } \\
\text { study period (2010-2012) }\end{array}$ & 71 \\
5 & $\begin{array}{l}\text { Companies with positive equity value } \\
\text { during the study period (2010-2012). }\end{array}$ & 64 \\
\hline & \begin{tabular}{l} 
The final amount of the sample \\
\hline
\end{tabular} & $\mathbf{6 4}$ \\
\hline
\end{tabular}

The results of the descriptive statistics for dependent, independent, and control variables are presented in Table $2 .^{1}$

The eco-efficiency variable is a dummy variable and it is measured by the acquisition of ISO 14001 certification. Companies that have an ISO 14001 certificate have a value of 1 and are deemed to be companies with eco-efficiency, while companies that are not ISO 14001 certified have a value of 0 and are deemed to be companies without eco-efficiency. Descriptive analysis for the eco-efficiency variable was indicated by the frequency of occurrence of the value 1 or 0 . Table 3 shows the number of companies which had acquired ISO 14001 certification during the period 2010-2012.

Prior to the regression test, the classical assumption test was carried out. ${ }^{2}$ The results

\footnotetext{
${ }^{1}$ Utami (2005) suggested that the negative sign in the CoE meant investors got a negative return, or it can be said investors bore losses on the investments that they made. This is because the company's book value plus the profit estimation was smaller than the company's stock price.

${ }^{2}$ In analyzing data we use a Pooled Least Square model (PLS) instead of a Fixed Effect Model (FEM) or Random Effect Model (REM) with the assumption that the constant between periods are the same and the unobserved effects are ignored.
}

showed that the classical assumptions were not violated. The regression test results are displayed in Table 4.

Table 4 shows that eco-efficiency has a coefficient value of -0.119 with a significance level of 0.026. These results indicate that ecoefficiency had a significant negative effect on the cost of equity capital. This means that ecoefficiency implemented by companies helped the companies in reducing their cost of equity capital. With regards to control variables, table 4 shows that only one control variable, that is the BtM ratio, significantly affected the cost of equity capital with a coefficient of 0.693 and a significance level of 0.000 . The other control variables, i.e. risk sensitivity of the stock, company size, and the level of corporate debt do not significantly affect the cost of equity capital. This is different to the findings of Botosan (1997) and Mangena et al. (2010) who found that the risk sensitivity of the stock, the company's size, and the level of corporate debt significantly affected the cost of equity capital.

\section{DISCUSSION}

The results of this study indicated that the independent variable, eco-efficiency, proxied using the acquisition of ISO 14001 environmental management certification, had a significantly negative effect on the cost of equity capital. The results demonstrated empirically that one of the benefits of eco-efficiency is that a company can gain a lower cost of equity capital. This supports the argument made by Hansen and Mowen (2007).

The results of this study are consistent with previous studies showing that eco-efficiency has a positive effect on the market value of the company (Guenster et al., 2006; Sinkin et al., 2008; Al-Najjar and Anfimiadou, 2012). The increased value of the company, as measured using its stock price, will lower the cost of equity capital. By way of these results, it can be proved that eco-efficiency negatively affects the cost of equity capital for manufacturing companies in Indonesia. 
Table 2. Descriptive Statistics of Variables Studied

\begin{tabular}{lrrrrrr}
\hline & Minimum & Maximum & Average & Standard Deviation & 25\% Quartile & 75\% Quartile \\
\hline BtM & 0.01 & 2.93 & 1.02 & 0.71 & 0.3883 & 1.5575 \\
Beta & -15.20 & 196.15 & 2.23 & 14.62 & 0.00 & 1.19 \\
LnSize & 3.22 & 12.64 & 6.86 & 2.18 & 5.47 & 7.87 \\
Lev & 0.04 & 0.88 & 0.47 & 0.19 & 0.32 & 0.63 \\
CoE & -1.28 & 4.49 & 0.11 & 0.81 & -0.56 & 0.53 \\
\hline $\mathbf{N}=\mathbf{1 9 2}$ & & & & & &
\end{tabular}

Table 3. Number of Companies with and without ISO 14001 Certification

\begin{tabular}{cccccc}
\hline \multicolumn{2}{c}{2010} & \multicolumn{2}{c}{2011} & \multicolumn{2}{c}{2012} \\
\hline ISO 14001 & No ISO 14001 & ISO 14001 & No ISO 14001 & ISO 14001 & No ISO 14001 \\
18 & 46 & 21 & 43 & 26 & 38 \\
\hline
\end{tabular}

Table 4. Regression Results

\begin{tabular}{lcccc}
\hline Variable & $\begin{array}{c}\text { Unstandardized } \\
\text { Coefficients }\end{array}$ & $\begin{array}{c}\text { Standardized } \\
\text { Coefficients }\end{array}$ & $\mathrm{t}$ & Sig. \\
\hline (Constant) & -0.555 & & -2.351 & 0.020 \\
ECO & -0.198 & -0.116 & -2.174 & 0.031 \\
BtM & 0.785 & 0.687 & 11.429 & 0.000 \\
Beta & -0.001 & -0.014 & -0.281 & 0.779 \\
LnSize & -0.013 & -0.036 & -0.575 & 0.566 \\
Lev & 0.043 & 0.010 & 0.209 & 0.834 \\
\hline F-test & & & & 50.609 \\
Sig. & & & & 0.000 \\
R EMBED Equation.3 & & & & 0.576 \\
Adjusted R EMBED Equation.3 & & & & 0.565 \\
\hline
\end{tabular}

The results of this study demonstrated that good environmental performance, which is reflected by the acquisition of ISO 14001, may reduce the risk borne by the investor. Investors respond to the disclosure of a company's ISO 14001 Environmental Management certification and they are more likely to invest in companies with such certification. The more investors there are and the higher the stock prices are, the lower the cost of equity capital for companies with eco-efficiency is likely to be, as compared to those without it. This is consistent with the findings of Jacobs et al. (2008) who stated that investors respond to the announcements by companies regarding environmental awards and certifications issued by third parties. The results of this study are quite surprising because investors in the Indonesian Stock Exchange, which is, in fact, still a developing capital market, are capable of responding to the disclosure of the ISO 14001 Environmental Management certification which results in a cost of equity capital that is lower for companies that implement ecoefficiency.

\section{CONCLUSIONS, LIMITATIONS AND SUGGESTIONS}

The primary objective of this study was to examine the effect of eco-efficiency on the cost of equity capital for companies listed on the Indonesian Stock Exchange. The results demonstrated empirically that eco-efficiency, as measured by the acquisition of ISO 14001 Environmental Management certification, and having this certification has a significant negative effect on the company's cost of equity capital. This 
means that companies that implement ecoefficiency had a cost of equity capital lower than companies without eco-efficiency. These results are consistent with the argument by Hansen and Mowen (2007) which stated that one of the benefits of eco-efficiency was that a company could gain a lower cost of equity capital. Therefore, based on the findings we suggest that companies should implement the eco-efficiency paradigm as this may reduce their costs of equity capital.

The results of this study indicate that investors evaluate companies which, because of ecoefficiency, are expected to pose low environmental risks and so are more trusted by those investors as they look to make their investments. This reduces the cost of equity capital for companies compared to those without eco-efficiency. In addition, the results of this study indicate that investors in Indonesia are able to respond to the disclosure of ISO 14001 Environmental Management certification. These results are consistent with the findings of Jacobs et al. (2008) which stated that investors respond to company announcements regarding environmental awards and certification from third parties.

Nevertheless, this study has limitations which must be borne in mind when interpreting the results and which can become considerations for subsequent research in order to obtain better findings. These limitations include the following. First, this study only used the acquisition of ISO 14001 Environmental Management certification to measure eco-efficiency in terms of its effect on the cost of equity capital. Future studies could be validated by using other tools to measure eco-efficiency. Second, this study only examined the effect of eco-efficiency on the cost of equity capital, instead of examining the influence of the cost of capital in a comprehensive way. Future studies could develop this research by incorporating other types of cost of capital. Third, the cost of equity capital was measured using a modified version of the Ohlson Model (1995). Future studies could test this study by using a different measure of the cost of equity. Fourth, the data used by this study were only from the financial reporting period 2010-2012. This was due to limitations of the data obtained from the Indonesian Stock Exchange. Future studies could use data from longer periods. Fifth, the financial statement data used in this study had not been prepared in accordance with International Financial Reporting Standards (IFRS). Future studies could conduct the test using data from financial statements that are already IFRS compliant. Regardless of these limitations, this study has provided preliminary evidence that the application of eco-efficiency can lower the cost of equity capital.

\section{REFERENCES}

Al-Najjar, B., \& Anfimiadou, A. (2011). Environmental Policies and Firm Value. Business Strategy and the Environment, Vol. 21, 49-59.

BPS (Badan Pusat Statistik): Pendapatan Domestik Bruto. (2013). Available at: http://www.bps.go.id/brs_file/pdb_05feb13. pdf accessed November 24, 2013.

Bran, F., Radulescu, C. V., \& Ioan, I. (2011). Measures of Environmental Performance. Review of International Comparative Management , 893-900.

Botosan, C. (1997). Disclosure Level and The Cost of Equity Capital. The Accounting Review, Vol. 40, No.1 : 223-349.

Clarkson, P. M., Overell, M. B., \& Chapple, L. (2011). Environmental Reporting and its Relation to Corporate Environmental Performance. Abacus: A Journal of Accounting, Finance, and Business Study, Vol. 47, 2760.

Deegan, C., \& Rankin, M. (1996). Do Australian Companies Report Environmental News Objectively?: An Analysis of Environmental Disclosures by Firms Prosecuted Successfully by The Environmental Protection Authority. Accounting, Auditing \& Accountability Journal, Vol. 9, No. 2: 50-67.

De Francia, J. Canon \& C. Garces-Ayerbe. (2006). ISO 14001 Environmental Certification: A Sign Valued by Market?. Springer: Spain.

Drake, P. P. (2011). Dividend Valuation Models. Available at: http://educ.jmu.edu/ drakepp/ FIN362/resources/dvm.pdf. Accessed Januari 15, 2014, 
Eiteman, D. K., Stonehill, A. I., \& Moffett, M. H. (2010). Multinational Business Finance. Boston: Pearson Education, Inc.

BIBLIOGRAPHY ll 1057 El-Ghoul, S., Guedhami, O., Kwok, C. C., \& Mishra, D. R. (2011). Does Corporate Social Responsibility Affect the Cost of Capital? Journal of Banking \& Finance, Vol. 25, 2388-2406.

Environmental Performance Index and Pilot Trend Environmental Performance Index.(2012). in http://www.epi.yale.edu/. Accessed Monday, 6 Januari 2014.

Fact Book 2011.pdf. Available at: http://www. idx.co.id/. Accessed Friday, 15 November 2013.

Fact Book 2012.pdf. Available at: http://www. idx.co.id/. Accessed Friday, 15 November 2013.

Fact Book 2013.pdf. Available at: http://www. idx.co.id/. Accessed Friday, 15 November 2013.

Ghozali, I. and Chariri, A. (2007). Teori Akuntansi. Semarang: Badan Penerbit Universitas Diponegoro.

BIBLIOGRAPHY Vl 1057 Guenster, N., Derwall, J., Bauer, R., Koedijk, K. (2006). The Economic Value of Corporate Ecoefficiency. Rotterdam: Erasmus University.

Gujarati, D. N., dan D. C. Porter. (2009). Basic econometrics international edition $\left(5^{\text {th }} \mathrm{Ed}\right)$. New York: McGraw-Hill Companies.

Hansen, D. R., \& Mowen, M. M. (2007). Managerial Accounting. Mason: South-Western Cengage Learning.

Irawan, R. \& Murhadi, W. R. (2012). Analisis Pengaruh Three Factor Model dan Persentase Kepemilikan Asing Terhadap Tingkat Return di Bursa Efek Indonesia. Available at: http://www.academia.edu/3173848. Accessed Thursday, 9 Januari 2014.

Jacobs, W. B., Singhal, R. V., Subramanian, R. (2008). The Economic Value of Corporate Eco-efficiency. Atlanta: Georgia Institute of Technology.

Mangena, M., Pike, R. Li, J. (2010). Intellectual Capital Disclosure Practices and Effects on the Cost of Equity Capital: UK Evidence. Edinburgh: The Institute of Chartered Accountants of Scotland.
BIBLIOGRAPHY \l 1057 Mardiyah, A. A. (2002). Pengaruh Informasi Asimetri dan Disclosure terhadap Cost of Capital. The Indonesian Journal of Accounting Research , 229-256.

Marshall, R., \& Brown, D. (2003). Corporate Environmental Reporting: What's in a Metric? Business Strategy and The Environment, Vol. 12, 87-106.

BIBLIOGRAPHY \l 1057 Modigliani, F., \& Miller, M. H. (1958). The Cost of Capital, Corporation Finance, and The Theory of Investment. The American Economic Review , 261-297.

BIBLIOGRAPHY \l 1057 Rini, W. (2002). Pengaruh Model Mekanik, Ukuran Perusahaan, dan Rasio Ungkitan pada Ketepatan Prakiraan Laba. Paper presented in Simposium Nasional Akuntansi 5. Semarang.

BIBLIOGRAPHY \l 1057 Saha, A. K., \& Akter, S. (2013). Relationship Between Environmental Reporting in Corporate Annual Report \& Corporate Profitability in Bangladesh. Global Conference on Business and Finance Proceedings , 75-86.

BIBLIOGRAPHY \ 1057 Sarkis, J., \& Talluri, S. (2004). Eco-efficiency Measurement Using Data Envelopment Analysis: Research and Practitioner Issues. Journal of Environmental Assessment Policy and Management, Vol. 6, No. 1: 91-123.

BIBLIOGRAPHY \l 1057 Sekaran, U., \& Bougie, R. (2010). Research Method for Business. United Kingdom: John Wiley \& Son.

Setyorini, C. T., \& Ishak, Z. (2012). Corporate Social and Environmental Reporting: A Case of Mimetic Isomorphism. American International Journal of Contemporary Research , Vol. 2, No. 5: 11-17.

BIBLIOGRAPHY $\backslash 1057$ Sinkin, C., Wright, C. J., \& Burnett, R. D. (2008). Eco-efficiency and Firm Value. Journal of Accounting and Public Policy, Vol. 27 , 167-176.

Sistem Manajemen Lingkungan - Persyaratan dan Panduan Penggunaan.pdf. Available at: http://www.sni.go.id/. Accessed Friday, 18 Oktober 2013.

Suryaningsih, Ika. 2011. Pengaruh Kinerja Lingkungan Berbasis ISO 14001 dan Pengungkapan Informasi Lingkungan Sukarela 
terhadap Kinerja Ekonomi (Studi Empiris Perusahaan Pertambangan dan Energi yang Tercatat di Bursa Efek Indonesia). Unpublished Undergraduate Thesis. FEB UGM. Yogyakarta

Sutrisno. (2005). Manajemen Keuangan Teori, Konsep, dan Aplikasi. Yogyakarta: Ekonisia. BIBLIOGRAPHY $\backslash 1057$

BIBLIOGRAPHY \l 1057 BIBLIOGRAPHY \l 1057 Utami, W. (2005). Pengaruh Manajemen Laba terhadap Biaya Modal Ekuitas
(Studi pada Perusahaan Publik Sektor Manufaktur). Paper presented at Simposium Nasional Akuntansi VIII, Solo.

BIBLIOGRAPHY \l 1057 Weston, J. F., \& Brigham, E. F. (1972). Managerial Finance 4th edition. San Diego: Harcourt Brace.

World Business Council for Sustainable Development Report. (2000). Ecoefficiency: Creating More Value with Less Impact. Available at: http//www.wbcsd.org. 